\title{
Equilibrium and kinetic studies on ligand substitution reactions of chloromethyl(aquo)cobaloxime with aromatic and aliphatic $\mathrm{N}$-donor ligands
}

\author{
D SUDARSHAN REDDY and S SATYANARAYANA* \\ Department of Chemistry, Osmania University, Hyderabad 500 007, India \\ e-mail: ssnsirasani@yahoo.com
}

MS received 21 February 2003; revised 13 May 2003

\begin{abstract}
Equilibria and kinetics of the reactions of chloromethyl(aquo)cobaloxime with histamine, histidine, glycine and ethyl glycine ester were studied as a function of $\mathrm{pH}$ at $25^{\circ} \mathrm{C}, 1.0 \mathrm{M}$ ionic strength $(\mathrm{KCl})$ by spectrophotometric techniques. Comparison of equilibrium constants and rate constants tells that the order is

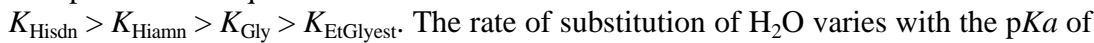
the incoming ligand and nucleophilic participation of the ligand in the transition state. The rate constants and equilibrium constants are correlated to the hardness and softness of the ligands and the Co(III) of cobaloxime.
\end{abstract}

Keywords. Alkylcobaloximes; ligand substitution reactions; hard and soft ligands.

\section{Introduction}

$\mathrm{B}_{12}$-based enzymes are among the few cofactors known till now contain a metal-carbon bond. Axial ligation reactions of metalloporphyrin and cobaloximes in aqueous solution are dependent upon the particular metal ion, ${ }^{1-3}$ equatorial ligands ${ }^{4}$ and the axial ligands. ${ }^{5-}$ ${ }^{7}$ The study of simple models of the $\mathrm{B}_{12}$ coenzyme, such as the cobaloximes, $\mathrm{RCo}(\mathrm{DH})_{2} \mathrm{~L}$, where $\mathrm{L}=$ neutral ligand and $\mathrm{R}=$ alkyl group, has furnished significant amounts of data, that have provided a foundation for understanding the behaviour of cobalamins. ${ }^{10}$ These have also been the subject of extensive kinetic and mechanistic studies. ${ }^{11}$ Ligand substitution reactions of coordinated $\mathrm{H}_{2} \mathrm{O}$ in aquocobalamin $\left(\mathrm{VitB}_{12}\right)$ by $\mathrm{OCN}^{-}, \mathrm{SCN}^{-}$, $\mathrm{CN}^{-}$and $\mathrm{N}_{3}^{-}$were reported by Marques and Knapton. ${ }^{12}$

Compared to cobalamins and other model systems, cobaloximes have stronger $\mathrm{Co}-\mathrm{C}$ bonds ${ }^{13}$ and shorter $\mathrm{Co}-\mathrm{L}\left(\mathrm{L}=\right.$ pyridine or substituted pyridines) bonds. ${ }^{9}$ Eldik et al ${ }^{14,15}$ studied the ligand substitution reactions of trans- $\left[\mathrm{Co}(\mathrm{en})_{2} \mathrm{Me}\left(\mathrm{H}_{2} \mathrm{O}\right)\right]^{2+}$ a simple model for coenzyme $\mathrm{B}_{12}$, with cyanide and imidazole as entering ligands, and found that these ligands displace the coordinated water molecule trans to the methyl group and form the six-coordinate complex. There is a need to study ligand substitution reactions trans to the axial alkyl ligand in coenzyme $\mathrm{B}_{12}$ and various model complexes. It is known that methyl cobaloximes and coenzyme $\mathrm{B}_{12}$ undergo substitution of their axial benzimidazole ligand with protein histidine residues during complexation to the enzymes methionine synthase and methyl malonyl coenzyme A mutase respectively. ${ }^{16,17}$

*For correspondence 
Since cobaloximes with amino acids and histamine are more closely related to the structural and bonding characteristics of corrin systems involved in biological mechanisms, we decided to explore the kinetics and equilibria of the axial ligation of chloromethyl(aquo)cobaloximes with ambidentate aromatic ligands (histamine, histidine) and unidentate aliphatic ligands (glycine, ethyl glycine ester).

\section{Materials and methods}

Histamine (histamine dihydrochloride), histidine (histidine monohydrochloride), glycine, ethyl glycine ester were obtained from Sigma and were used without further purification. $\mathrm{KCl}$, HPLC grade methanol, acetic acid, $\mathrm{HCl}$, phosphoric acid, formic acid were obtained from Fluka. Dipotassium hydrogen phosphate, potassium dihydrogen phosphate, potassium phosphate, tris(hydroxymethyl)aminomethane (Tris), sodium acetate, potassium hydroxide were obtained from Acros. Double distilled, deionized water was used throughout.

To maintain appropriate $\mathrm{pH} 0.2 \mathrm{M}$ buffers of $\mathrm{HCl}(0-1.5 \mathrm{pH}), \mathrm{KH}_{2} \mathrm{PO}_{4}$ and $\mathrm{H}_{3} \mathrm{PO}_{4}(2 \cdot 0$ $\mathrm{pH}), \mathrm{HCOOH}$ and $\mathrm{KOH}(2.5-3.0 \mathrm{pH}), \mathrm{CH}_{3} \mathrm{COOH}$ and $\mathrm{CH}_{3} \mathrm{COONa}(3.5-5.5 \mathrm{pH})$, $\mathrm{K}_{2} \mathrm{HPO}_{4}$ and $\mathrm{KH}_{2} \mathrm{PO}_{4}(6 \cdot 0-8 \cdot 0 \mathrm{pH})$, Tris and $\mathrm{HCl}(8 \cdot 5-9 \cdot 0 \mathrm{pH}), \mathrm{K}_{2} \mathrm{HPO}_{4}$ and $\mathrm{K}_{3} \mathrm{PO}_{4}(9 \cdot 5-$ $11.5 \mathrm{pH})$ are used.

Chloromethyl(aquo)cobaloximes were prepared by the procedure of Brown et al ${ }^{18}$. All manipulations were performed under minimal illuminations due to the photolability of carbon-cobalt bond. These alkyl(aquo)cobaloximes are photolabile, particularly in solution. They are soluble in alcohols and DMSO, less so in chloroform or water and virtually insoluble in ether and hydrocarbon solvents.

Measurements of $\mathrm{pH}$ were made with a Digisun digital $\mathrm{pH}$-meter equipped with a combined glass electrode. The electrode was standardized at two $\mathrm{pH}$ values $(\mathrm{pH}=4$ and 9.2) with standard buffer solutions. UV and visible spectra were recorded at $435 \mathrm{~nm}$ on a Hitachi U-3410, the sample compartment of which is provided with a thermostat, and the concentration of chloromethyl(aquo)cobaloximes $(0 \cdot 00096 \mathrm{M})$ was fixed. For axial ligation, single wavelength measurements were made on an Elico single beam spectrophotometer SL 171 model, the sample compartment of which was thermostated at $25 \pm 0 \cdot 1^{\circ} \mathrm{C}$.

\section{Results and discussion}

\subsection{Determination of equilibrium constants}

Apparent equilibrium constants $\left(K_{\text {app }}\right)$ for the axial ligation of chloromethyl(aquo) cobaloximes were determined as below by spectrophotometric measurements at $435 \mathrm{~nm}$ ( $\lambda_{\max }$ of chloromethyl(aquo) cobaloxime). In $3 \mathrm{ml}$ cuvettes, solutions containing $\mathrm{ClCH}_{2} \mathrm{Co}(\mathrm{DH})_{2}\left(\mathrm{OH}_{2}\right)$, an appropriate buffer $(0 \cdot 2 \mathrm{M})$ to maintain $\mathrm{pH}, \mathrm{KCl}$ to maintain ionic strength $(1.0 \mathrm{M})$ and varying concentrations of ligand were taken and allowed to equilibrate in a thermostated holder at $25 \pm 0 \cdot 1^{\circ} \mathrm{C}$ for $15 \mathrm{~min}$ prior to addition of cobaloxime.

$$
K_{\text {app }}=\frac{\left[\mathrm{ClCH}_{2} \mathrm{Co}(\mathrm{DH})_{2} \mathrm{~L}\right]}{\left[\mathrm{ClCH}_{2} \mathrm{Co}(\mathrm{DH})_{2} \mathrm{H}_{2} \mathrm{O}\right][\mathrm{L}]_{\text {free }}} .
$$


Final absorbance readings were taken after equilibrium was established as indicated by the time independence of the readings. For such experimental setups, at a given $\mathrm{pH},(2)$ is applied,

$$
\Delta A=\Delta A_{\max }[\mathrm{L}]_{f} /\left(1 / K_{\text {app }}+[\mathrm{L}]_{f}\right)
$$

where $\Delta A$ is the difference in absorbance between solutions containing cobaloxime and added ligand (L) and solutions containing only cobaloxime at the same concentration, $\Delta A_{\max }$ is the maximum absorbance change thus obtained at high [L], and [L] $]_{f}$ is the unbound ligand concentration. The data were analysed by a least-squares fit to the rearranged form of (2) to give

$$
\begin{aligned}
& \Delta A=\Delta A_{\max }-\left\{1 / K_{\text {app }}\left(\Delta A /[\mathrm{L}]_{f}\right)\right\}, \\
& {[\mathrm{L}]_{f}=[\mathrm{L}]_{T}-\left(C_{T} \Delta A / \Delta A_{\text {max }}\right) .}
\end{aligned}
$$

$[\mathrm{L}]_{f}$ is calculated from (4) using the measured value of $\Delta A_{\max },[\mathrm{L}]_{T}$ is the total concentration of added ligand and $C_{T}$ is the total concentration of cobaloxime. Values of $K_{\text {app }}$ were obtained from the least-squares fit of (3), i.e. the plot of $\Delta A$ vs $\Delta A /[\mathrm{L}]_{f}$ and the slope is $-1 / K_{\text {app }}$. Values for the equilibrium constants for axial ligation with respect to unprotonated ligand were calculated from the relation $K_{\text {eq }}=K_{\text {app }} / \alpha_{\mathrm{L}}$, where $\alpha_{\mathrm{L}}$ is calculated from the relation $\alpha_{\mathrm{L}}=K_{a} /\left(K_{a}+\left[\mathrm{H}^{+}\right]\right)$.

\subsection{Determination of pseudo first-order rate constant $\left(k_{o n}\right)$}

For each ligand $\mathrm{L}$, at various $\mathrm{pH}$, first-order rate constants $\left(k_{\mathrm{obs}}\right)$ were determined from the absorbance measurements at the same wavelength used for $K_{\text {app }}$ determinations under pseudo first-order condition with $\mathrm{L}$ in at least 10 -fold excess over cobaloxime concentration (0.00096 M).

Reaction progress was monitored by measurements of the change in the absorbance upon addition of chloromethyl(aquo)cobaloxime to a $3 \mathrm{ml}$ cuvette, which contained $\mathrm{KCl}$ to maintained unit ionic strength, necessary buffer $(0 \cdot 2 \mathrm{M})$ to maintain $\mathrm{pH}$ and ligand in the thermostated $\left(25 \pm 0 \cdot 1^{\circ} \mathrm{C}\right)$ cell compartment. First-order rate constants $\left(k_{\text {obs }}\right)$ were obtained by least-squares fits of the data to (5) below,

$$
\ln \left(A_{t}-A_{\infty}\right)=k_{\mathrm{obs}} t
$$

where $A_{t}$ is the absorbance at time $t$ and $A_{\infty}$ is the final absorbance. Second-order rate constants, $k_{\text {on }}^{\prime}$, at a given $\mathrm{pH}$ for a given ligand were obtained from the slopes of leastsquares fits of the data to (6)

$$
k_{\mathrm{obs}}=k_{\mathrm{on}}^{\prime}[\mathrm{L}]_{T}+k_{\mathrm{off}},
$$

where $[\mathrm{L}]_{T}$ is the total concentration of $\mathrm{L}$ present. Values of $k_{\text {on }}^{\prime}$, the $\mathrm{pH}$ independent second-order ligation rate constant, were calculated from $k_{\mathrm{on}}=k_{\mathrm{on}}^{\prime} / \alpha_{\mathrm{L}}$, where $\alpha_{\mathrm{L}}$ is as defined above. 


\subsection{Determination of dissociation rate constant $\left(k_{\text {off }}\right)$}

Ligand dissociation rate constants, $k_{\text {off }}$ were measured spectrophotometrically by addition of a small volume of a solution containing preformed $\mathrm{ClCH}_{2} \mathrm{Co}(\mathrm{DH})_{2} \mathrm{~L}$ (usually $0.00096 \mathrm{M} \mathrm{ClCH}_{2} \mathrm{Co}(\mathrm{DH})_{2} \mathrm{OH}_{2}$ plus $0.00192 \mathrm{M}$ ligand in $25 \%$ methanol) to cuvettes containing $\mathrm{KCl}$ and buffer $(0 \cdot 2 \mathrm{M})$ in the thermostated $\left(25 \pm 0 \cdot 1^{\circ} \mathrm{C}\right)$ cell compartment of the spectrophotometer.

Absorbance was continuously monitored at the same wavelength $(435 \mathrm{~nm})$ used for $K_{\text {app }}$ and $k_{\text {obs }}$ measurements. Measurements were made in triplicate at each pH and firstorder rate constants, $k_{\text {off }}$, were determined as above, (5). In all cases, the ligand dissociation proceeded to $\geq 99 \%$ completion. All plots of (5) were satisfactorily linear (correlation coefficients $\geq 0.998$ ). All determinations were averaged to obtain a final value of $k_{\text {off }}$ as

$$
k_{\text {off }}=k \mathrm{I}+k \mathrm{II}\left[\mathrm{H}^{+}\right] .
$$

The values of the equilibrium constant $K_{\text {app }}$ for the reaction of the glycine, ethyl glycine ester, histidine and histamine with chloromethyl(aquo)cobaloximes are given in table 1 . Logarithmic plots of $\log K_{\text {app }} \mathrm{vs} \mathrm{pH}$ are shown in figure 1 which indicates that as the $\mathrm{pH}$ increases, the $K_{\text {app }}$ increases and the affinity for ligands to neutral chloromethyl (aquo) cobaloxime increase in the order Glyest $<$ Gly $<$ Hiamn $<$ Hisdn. If we compare the $\mathrm{pH}$ dependent binding plots of glycine and ethyl glycine ester in both cases, $K_{\text {app }}$ increases with increase in $\mathrm{pH}$ and after certain $\mathrm{pH}$ they become $\mathrm{pH}$-independent, glycine shows $\mathrm{pH}$ dependence up to a value of 10 and later becomes $\mathrm{pH}$-independent, whereas ethyl glycine ester binding is $\mathrm{pH}$-dependent up to $8 \mathrm{pH}$ and later becomes $\mathrm{pH}$ independent. The binding of histidine to chloromethyl(aquo)cobaloxime has been shown in figure 2 .

Table 1. Formation constants for the axial ligation of $\mathrm{ClCH}_{2} \mathrm{Co}$ $(\mathrm{DH})_{2} \mathrm{OH}_{2}$ by $\mathrm{L}$ at $25^{\circ} \mathrm{C}$.

\begin{tabular}{|c|c|c|c|c|}
\hline \multirow[b]{2}{*}{$\mathrm{pH}$} & \multicolumn{4}{|c|}{$\log K_{\text {app }}$ at different $\mathrm{pH}$ values for ligand } \\
\hline & Histidine & Histamine & Ethyl glycine ester & Glycine \\
\hline 4.5 & 2.44 & $2 \cdot 10$ & - & - \\
\hline $5 \cdot 0$ & $2 \cdot 92$ & 2.59 & - & - \\
\hline $5 \cdot 5$ & 3.38 & 3.06 & - & - \\
\hline $6 \cdot 0$ & 3.75 & $3 \cdot 46$ & - & - \\
\hline $6 \cdot 5$ & 3.99 & 3.76 & 1.91 & - \\
\hline 7.0 & $4 \cdot 11$ & 3.92 & $2 \cdot 47$ & - \\
\hline $7 \cdot 5$ & $4 \cdot 16$ & 3.98 & $2 \cdot 82$ & $1 \cdot 27$ \\
\hline 8.0 & $4 \cdot 17$ & $4 \cdot 01$ & $3 \cdot 04$ & 1.76 \\
\hline 8.5 & $4 \cdot 18$ & $4 \cdot 01$ & $3 \cdot 13$ & 1.25 \\
\hline $9 \cdot 0$ & $4 \cdot 18$ & 4.02 & $3 \cdot 17$ & $2 \cdot 70$ \\
\hline 9.5 & - & - & 3.18 & 3.07 \\
\hline 10 & - & - & $3 \cdot 19$ & $3 \cdot 32$ \\
\hline $10 \cdot 5$ & - & - & $3 \cdot 19$ & 3.44 \\
\hline 11.0 & - & - & - & 3.49 \\
\hline$K_{\mathrm{eq}}$ & 15180 & 10418 & 1550 & 3250 \\
\hline
\end{tabular}




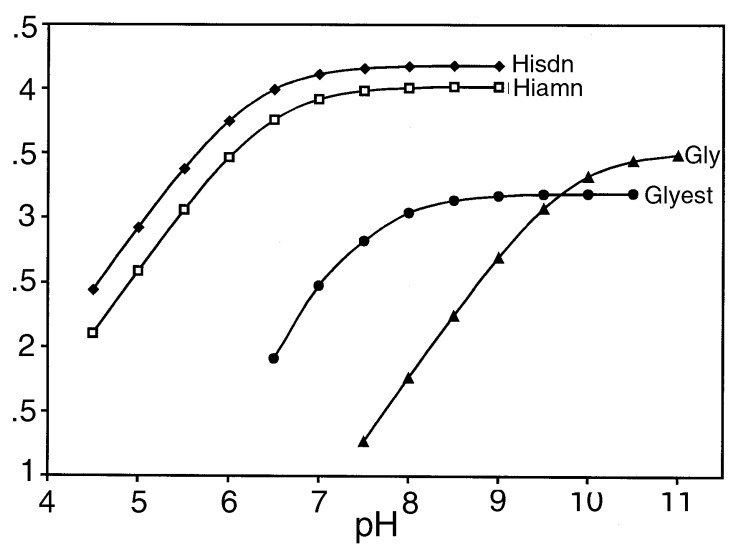

Figure 1. Dependence of $\log K_{\text {app }}$ on the $\mathrm{pH}$ for the axial ligation of chloromethyl (aquo)cobaloxime by different ligands at $25^{\circ} \mathrm{C}$.

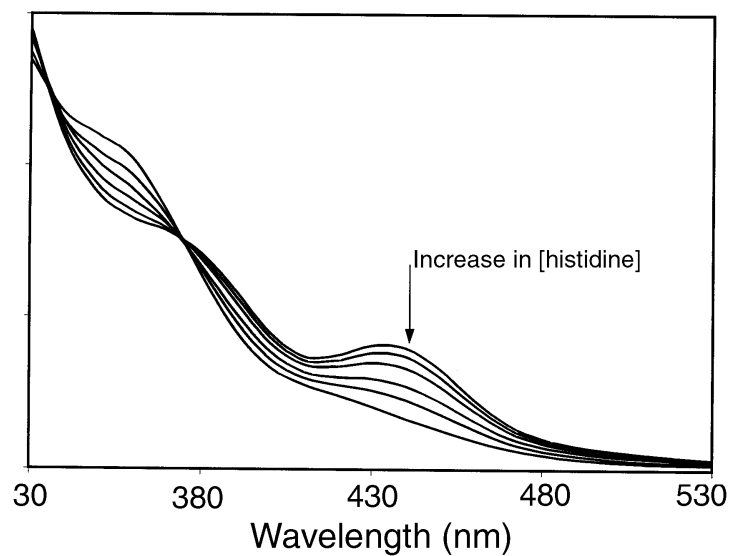

Figure 2. Binding of $\mathrm{ClCH}_{2} \mathrm{Co}(\mathrm{DH})_{2} \mathrm{H}_{2} \mathrm{O}$ with varying concentrations of histidine at $\mathrm{pH}=6.5$ and $25^{\circ} \mathrm{C}$, isosbestic point $=376 \mathrm{~nm}$.

Pseudo first-order rate constants are dependent on the $\mathrm{pH}$. It is found that as $\mathrm{pH}$ is increased, rate constant also increases. In the case of histamine and histidine there is no increase in $K_{\text {app }}$ at the $\mathrm{pH}$ above the $\mathrm{pKa}$ of the ligand. This clearly indicates that in these ligands the binding is through the endocyclic nitrogen. If it binds through the $\mathrm{NH}_{2}$ group, there should be an increase in $K_{\text {app }}$ at higher $\mathrm{pH}$, that is above the $\mathrm{p} K a$ of the ligand. With histidine, the coordination is through the nitrogen of the imidazole ring, though there is a possibility of $\mathrm{COO}^{-}$and $\mathrm{NH}_{2}$ coordination, the $\mathrm{NH}_{2}$ is mostly protonated below $8.0 \mathrm{pH}$. The plots of the pseudo first-order rate constants as a function of ligand concentration give straight lines with intercepts, the slope of which is $k_{\text {on }}^{\prime}$. It is observed that as $\mathrm{pH}$ increases there is increase in $k_{\text {obs }}$ and there is decrease in $k_{\text {off. }}$. All the kinetic results are summarized in table 2 . 
Table 2. Kinetic data for the axial ligation of chloromethyl(aquo)cobaloxime by different ligands at $25^{\circ} \mathrm{C}$.

\begin{tabular}{|c|c|c|c|c|c|c|c|c|}
\hline \multicolumn{3}{|c|}{$k_{\mathrm{obs}}\left(\mathrm{s}^{-1}\right)$} & \multicolumn{3}{|c|}{$k_{\text {off }}\left(\mathrm{s}^{-1}\right)$} & \multicolumn{3}{|c|}{$k_{\mathrm{obs}}\left(\mathrm{s}^{-1}\right)$} \\
\hline $\mathrm{pH}$ & Histidine & Histamine & $\mathrm{pH}$ & Histidine & Histamine & $\mathrm{C}: \mathrm{L}^{*}$ & Histidine & Histamine \\
\hline $3 \cdot 5$ & - & $1.5 \times 10^{-3}$ & $2 \cdot 0$ & - & $8.0 \times 10^{-3}$ & $1: 10$ & $1.20 \times 10^{-3}$ & $1.80 \times 10^{-3}$ \\
\hline $4 \cdot 0$ & - & $1.8 \times 10^{-3}$ & $2 \cdot 5$ & - & $4.9 \times 10^{-3}$ & $1: 15$ & $2.00 \times 10^{-3}$ & $1.86 \times 10^{-3}$ \\
\hline $4 \cdot 5$ & - & $2.5 \times 10^{-3}$ & $3 \cdot 0$ & $2.5 \times 10^{-3}$ & $2.5 \times 10^{-3}$ & $1: 20$ & $2 \cdot 80 \times 10^{-3}$ & $1.90 \times 10^{-3}$ \\
\hline $5 \cdot 0$ & $1.2 \times 10^{-3}$ & $4.0 \times 10^{-3}$ & $3 \cdot 5$ & $1.9 \times 10^{-3}$ & $1.6 \times 10^{-3}$ & $1: 25$ & $3.40 \times 10^{-3}$ & $1.96 \times 10^{-3}$ \\
\hline $5 \cdot 5$ & $2.4 \times 10^{-3}$ & $4.4 \times 10^{-3}$ & $4 \cdot 0$ & $1.5 \times 10^{-3}$ & & $1: 30$ & $4.00 \times 10^{-3}$ & $2.00 \times 10^{-3}$ \\
\hline $6 \cdot 0$ & $5 \cdot 1 \times 10^{-3}$ & & $4 \cdot 5$ & $1.4 \times 10^{-3}$ & & $1: 35$ & $4.80 \times 10^{-3}$ & $2.04 \times 10^{-3}$ \\
\hline $6 \cdot 5$ & $6.0 \times 10^{-3}$ & & & & & $k_{\mathrm{on}}^{\prime}\left(\mathrm{dm}^{3}\right.$ & $0 \cdot 1464$ & 0.01 \\
\hline $7 \cdot 0$ & $6.2 \times 10^{-3}$ & & & & & $\left.\mathrm{~mol}^{-1} \mathrm{~s}^{-1}\right)$ & & \\
\hline & & & & & & $\begin{array}{c}\alpha \\
k_{\mathrm{on}}\left(\mathrm{dm}^{3}\right. \\
\left.\mathrm{mol}^{-1} \mathrm{~s}^{-1}\right)\end{array}$ & $\begin{array}{c}5.56 \times 10^{-2} \\
2.63\end{array}$ & $\begin{array}{c}3.87 \times 10^{-3} \\
2.58\end{array}$ \\
\hline
\end{tabular}

*Ratio of $\left[\mathrm{ClCH}_{2} \mathrm{Co}(\mathrm{DH})_{2} \mathrm{OH}_{2}\right]\left(9.6 \times 10^{-4}\right) \mathrm{M}$ and $[\mathrm{L}] \mathrm{M}$

A soft or class b character has been assigned to $\mathrm{Co}(\mathrm{IIII})$ in cobaloximes ${ }^{19}$ and is consistent with the observed greater ligand affinity of cyanide, imidazole,${ }^{20-23}$ histidine or histamine than that of the hard glycine or ethyl glycine ester. Furthermore, softness appears to be related to the ability of a cobalt complex to stabilize a $\mathrm{Co}-\mathrm{C}$ bond. $\mathrm{Co}$ (III) to ligand $\pi$ bonding is used to explain the reverse order for the dependence of ligation strength upon ligand basicity. The order of $\mathrm{ClCH}_{2} \mathrm{Co}(\mathrm{DH})_{2} \mathrm{~L}$ stability is attributed to the ability of imidazoles or histidine or histamine to accept electrons into higher energy unfilled $\pi^{*}$ anti-bonding orbitals through $\mathrm{d} \pi \rightarrow p \pi$ back bonding, whereas primary amines (glycine or ethyl glycine ester) cannot accept electrons in either fashion. The reverse order for the dependence of $\mathrm{ClCH}_{2} \mathrm{Co}(\mathrm{DH})_{2} \mathrm{~L}$ stability on ligand basicity among two series of ligands, aromatic (histamine and histidine) and aliphatic (glycine and ethyl glycine ester) is not unexpected based on the following reasons.

(1) An increase in basicity is associated with increased ability for $\sigma$ donation, for example glycine forms more stable complexes than ethyl glycine ester, since glycine is more basic ( $\mathrm{pKa}$ 9.74) than ethyl glycine ester ( $\mathrm{p} K \mathrm{a}$ 7.62).

(2) An increase in basicity is associated with decreased ability for the aromatic ligands to function as $\pi$ acceptors. Hence, $K_{\text {histidine }}>K_{\text {hiamn }}$, though histamine is slightly more basic than histidine. Histidine and histamine bind to $\mathrm{Co}(\mathrm{III})$, via $\mathrm{N} \rightarrow \mathrm{Co}$ (III) as well as $\mathrm{Co}(\mathrm{III}) \rightarrow \mathrm{N} \pi$ bond. Histidine is a better $\pi$ acceptor than histamine, hence histidine forms more stable complexes than histamine.

Figure 3 shows the association of histidine with $\mathrm{ClCH}_{2} \mathrm{Co}(\mathrm{DH})_{2} \mathrm{OH}_{2}\left(\mathrm{pKa}=11.95^{24}\right)$ at a fixed $\mathrm{pH}$ with time. The kinetics of substitution of the axial base in alkylcobaloximes and related cobalt complexes has been studied under a variety of conditions. ${ }^{25,26}$ In none of the studies was the mechanism established conclusively although in all cases strong evidence was obtained that the intimate mechanism is dissociative (Id or $D$ ).

The small dependence of $k_{\text {on }}$ upon ligand basicity within each series of ligands is clearly related to the fact that while the reacting complex is a soft acid, the ligand is hard. The rate constants are better correlated with the relative softness of the ligand. 
The stability of pentacoordinate alkyl cobalt complexes and the evidence that both the dominant soft $\mathrm{Co}(\mathrm{III})$ complexes, $\left[\mathrm{Co}(\mathrm{CN})_{5} \mathrm{H}_{2} \mathrm{O}\right]^{2-}$ and $\left[\mathrm{Co}\left(\mathrm{NH}_{3}\right)_{5} \mathrm{SO}_{3}\right]^{+}$, undergo ligand substitution reaction as $\mathrm{SN}^{1}$ mechanism, ${ }^{27,28}$ clearly favour this mechanism for ligation reaction of $\mathrm{ClCH}_{2} \mathrm{Co}(\mathrm{DH})_{2} \mathrm{OH}_{2}$. The coordination between the softness of a cobalt(III) complex and the stability of its pentacoordinate species permits an $\mathrm{SN}^{1}$ mechanism for ligand substitution. ${ }^{29}$

Figure 4 shows the dissociation of histidine from $\left[\mathrm{ClCH}_{2} \mathrm{Co}(\mathrm{DH})_{2} \mathrm{Hisdn}\right]$ at a fixed $\mathrm{pH}$ with time. The plot of pseudo first-order rate constant $k_{\text {obs }}$ against histidine or histamine concentration is linear with a very small intercept, which may indicate that a small dissociation is accompanied by complex formation. This appears to be more likely at lower $\mathrm{pH}$ (i.e. much below the $\mathrm{pKa}$ of histidine or histamine); this is probably due to the protonation of ligand. Kinetic studies could not be taken up at high $\mathrm{pH}$ by conventional

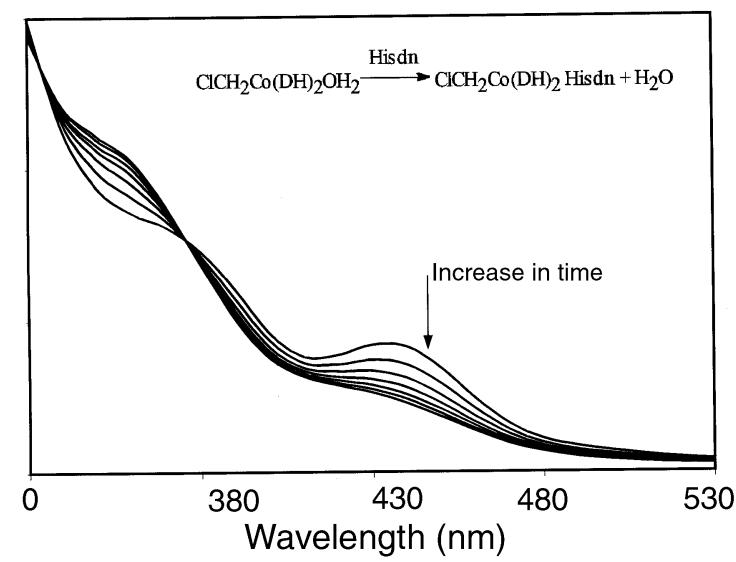

Figure 3. Association kinetics of $\mathrm{CICH}_{2} \mathrm{Co}(\mathrm{DH})_{2} \mathrm{H}_{2} \mathrm{O}$ with Hisdn at $\mathrm{pH}=5 \cdot 5$ and $25^{\circ} \mathrm{C}$, isosbestic point $=376 \mathrm{~nm}$

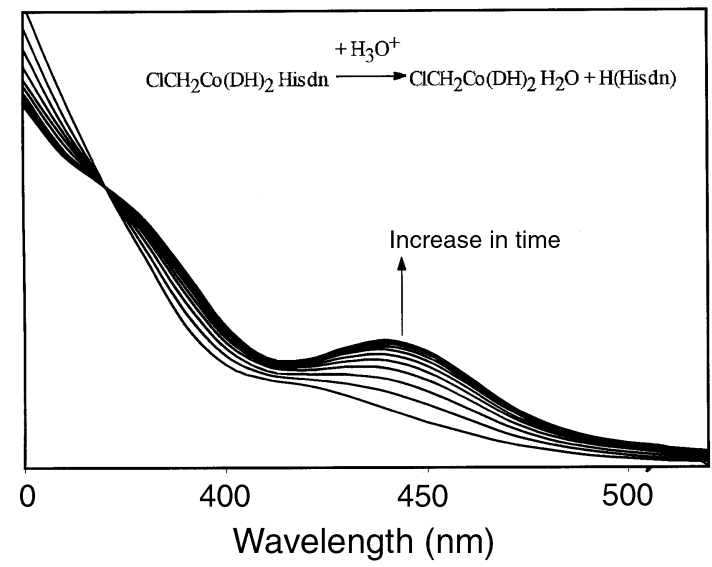

Figure 4. Dissociation kinetics of $\mathrm{ClCH}_{2} \mathrm{Co}(\mathrm{DH})_{2} \mathrm{Hisdn}$ into $\mathrm{ClCH}_{2} \mathrm{Co}(\mathrm{DH})_{2} \mathrm{H}_{2} \mathrm{O}$ at $\mathrm{pH}=1 \cdot 0$ and $25^{\circ} \mathrm{C}$, isosbestic point $=376 \mathrm{~nm}$. 


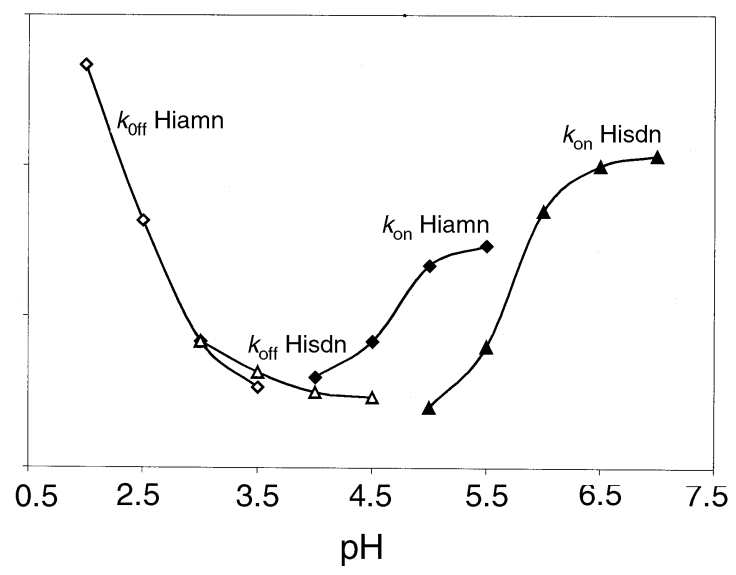

Figure 5. Dependence of $k_{\mathrm{obs}}$ on the $\mathrm{pH}$ for the axial ligation of chloromethyl (aquo) cobaloxime at $25^{\circ} \mathrm{C}$.

methods due to fast reactions. This is supported by the observed high binding constant values at high $\mathrm{pH}$. In case of histidine and histamine, as the $\mathrm{pH}$ is increased the rate of formation of complex increases. In case of histamine there is not much change in the $k_{\mathrm{obs}}$ even the $\mathrm{pH}$ is increased above 7.0. In both the cases, as the $\mathrm{pH}$ is decreased from a value of 4.0 the rate of dissociation is initially constant but on reaching 2.5 there is a sudden increase in the dissociation rate constant. That means the bound histamine or histidine comes out from the complex at lower $\mathrm{pH}$ easily. This supports the very low binding constant at lower $\mathrm{pH}$ and high binding constant at higher $\mathrm{pH}$. The rate of dissociation $\left(k_{\text {off }}\right)$ increases with decreasing $\mathrm{pH}$ (figure 5).

To compare the rate constants of the various ligands for the formation of complex with $\left[\mathrm{ClCH}_{2} \mathrm{Co}(\mathrm{DH})_{2} \mathrm{OH}_{2}\right]$, we have calculated second-order rate constant, $k_{\text {on }}^{\prime}$, from the slopes of the pseudo first-order rate constants as a function of concentration of the ligand. Since this is also $\mathrm{pH}$-dependent, for better comparison we have calculated $k_{\mathrm{on}}$, the $\mathrm{pH}$ independent second-order rate constant. The order of $k_{\text {on }}$ is as follows $\mathrm{CN}^{-} \gg 1$ Meimd $^{11}>$ Imd $>$ Histidine $>$ Histamine $>$ Gly $>$ Etglyest. This is in accordance with the order of basicity and $\pi$ back-bonding ability of the ligands. Though the basicities of glycine and ethyl glycine ester are larger than that of imidazole, histidine, or histamine the $k_{\text {on }}$ of glycine and ethylglycine ester are much smaller. But among glycine and ethyl glycine ester again, they follow the basicity order, $k_{\text {on }}$ of glycine $>$ ethyl glycine ester. This can be explained based on $\pi$ back-bonding and HSAB principle. Since imidazole and $\mathrm{CN}^{-}$are less basic than glycine, these react much faster due to the ability of $\pi$ backbonding in addition to $\sigma$ bond and soft-soft interaction between $\mathrm{Co}(\mathrm{III})$ and $\mathrm{CN}^{-}$or imidazole.

\section{Conclusions}

In the ligation reaction of $\mathrm{ClCH}_{2} \mathrm{Co}(\mathrm{DH})_{2} \mathrm{OH}_{2}$ the $\pi$-accepting ligands (cyanide, imidazole, histidine or histamine) react more rapidly than the purely $\sigma$ donor (glycine or ethyl glycine ester). The greater reactivity of the histidine and histamine compared to 
glycine or ethyl glycine ester stands in contrast to the opposite reactivity order for these nucleophiles with various unsaturated carbon electrophiles.

\section{Acknowledgements}

We gratefully acknowledge the University Grants Commission, New Delhi for financial support.

\section{References}

1. Ashley K R and Leipoldt G J 1981 Inorg. Chem. 202326

2. Leipoldt G J, Van Eldik R and Kelm H 1983 Inorg. Chem. 224146

3. Ashley K R, Shyu S and Leipoldt G J 1980 Inorg. Chem. 191613

4. Choo P L, Mulichak A M, Jones Jr. R W, Bacon J W and Pett V B 1990 Inorg. Chim. Acta 171183

5. Brown K L and Satyanarayana S 1992 Inorg. Chim. Acta 201113

6. Hirota S, Kosugi E, Marzilli L G and Yamauchi O 1998 Inorg. Chim. Acta 27590

7. Rajeshwar Rao A, Sridhar V and Satyanarayana S 1999 Proc. Indian Natl. Acad. Sci. A69 1

8. Randaccio L, Bresciani-Pahor N, Zangardo E and Marzilli L G 1989 Chem. Soc. Rev. 16 229

9. Bresciani-Pahor N, Forcolin M, Marzilli L G, Randaccio L, Summers M F and Toscano P J 1985 Coord. Chem. Rev. 631

10. Kim S H, Chen H L, Feilchenfeild N and Halpern J 1988 J. Am. Chem. Soc. 1103120

11. Sudarshan Reddy D, Rajeswar Rao A and Satyanarayana S 2002 Indian J. Chem. $\mathbf{4 4 1} 2475$

12. Marques H M, Knapton L, Xiang Zou and Brown K L 2002 J. Chem. Soc., Dalton Trans. 3195

13. Halpern J 1983 J. Pure Appl. Chem. 553677

14. Hamza M S A, Ducker-Benfer C and Van Eldik R 2000 Inorg. Chem. 393777

15. Alzoobi B M, Hamza M S A, Ducker-Benfer C and Van Eldik R 2002 Eur. J. Chem. 968

16. Drennan C L, Huang S, Drummond J T, Mathews R G and Ludwig M C 1994 Science 266 2669

17. Manica F, Keep N H, Nakagawa A, Leadlay P F, McSwerney S, Ramussen B, Bosake P, Diat O and Evans P R 1996 Structure 4229

18. Brown K L 1986 Organometallic syntheses (eds) R B King and J J Eisch (Amsterdam: Elsevier) 3186

19. Hague D N and Halpern J 1967 J. Inorg. Chem. 62059

20. Sridhar V and Satyanarayana S 2000 Proc. Indian Acad. Sci. (Chem. Sci.) 112579

21. Sridhar V and Satyanarayana S 2001 Indian J. Chem. A40 165

22. Sridhar V, Sudarshan Reddy D, Ravikumar Reddy N and Satyanarayana S 2002 Proc. Indian Acad. Sci. (Chem. Sci.) $\mathbf{1 1 4} 1$

23. Sridhar V, Sudarshan Reddy D, Ravikumar Reddy N and Satyanarayana S 2002 Proc. Indian Acad. Sci. (Chem. Sci.) 11411

24. Garlatti R D, Taugher G and Costa G 1983 Inorganic. Chim. Acta 719

25. Poon C K 1973 Coord. Chem. Rev. 101

26. Herlinger A W and Brown T L 1972 J. Am. Chem. Soc. 94388

27. Haim A J, Grassi R J and Wilmarth W K 1965 Advan. Chem., No. 49

28. Halpern J, Palmer R A and Blakley L M 1966 J. Am. Chem. Soc. 882877

29. Firth R A, Hill H A O, Pratt J M, Thorp R G and Williams R J 1969 J. Chem. Soc. A 381 